\title{
Nutritional properties of tubers of conventionally bred and transgenic lines of potato resistant to necrotic strain of Potato virus $Y\left(\mathrm{PVY}^{\mathrm{N}}\right)^{\star}$
}

\author{
Jerzy Juśkiewicz ${ }^{\bowtie}$ Zenon Zduńczyk and Józef Fornal \\ Institute of Animal Reproduction and Food Research of the Polish Academy of Sciences, Olsztyn, Poland; \\ $\otimes_{\mathcal{e}-m a i l: ~ g l e b c z o @ p a n . o l s z t y n . p l}$
}

Received: 15 March, 2005; revised: 30 August, 2005; accepted: 05 September, 2005 available on-line: 15 September, 2005

\begin{abstract}
The potential effect of genetic modification on nutritional properties of potatoes transformed to improve resistance to a necrotic strain of Potato virus $Y$ was determined in a rat experiment. Autoclaved tubers from four transgenic lines were included to a diet in the amount of $40 \%$ and compared with the conventional cv. Irga. The experiment lasted 3 weeks and special attention was paid to nutritional properties of diets, caecal metabolism and serum indices. Genetic modification of potato had no negative effect on the chemical composition and nutritional properties of tubers, ecosystem of the caecum, activity of serum enzymes and non-specific defence mechanism of the rats. Obtained results indicate that transgenic potato with improved resistance to PVYN: line R1F (truncated gene coding for PVYN polymerase in sense orientation), R2P (truncated gene coding for PVYN polymerase in antisense orientation), and NTR1.16 (non-translated regions of $\mathrm{PVY}^{\mathrm{N}}$ genome in sense orientation) are substantial and nutritional equivalence to the non-transgenic cultivar. Tubers of transgenic line NTR2.27 (non-translated regions of PVYN genome in antisense orientation) increased the bulk of caecal digesta and the production of SCFA as compared to tubers of the conventional cultivar and the other transgenic clones. Taking into account some deviations, it seems reasonable to undertake a long-term feeding study to confirm the nutritional properties of tubers of transgenic lines.
\end{abstract}

Keywords: potato, genetic modification, nutritional value, serum, ceacal fermentation, rat

The potato crop may be affected by many biotic and abiotic factors, pathogens and environmental stress. When pathogens are not properly controlled, the potato yield of infected plants may be reduced by $80 \%$. This is a serious economic problem in countries where potatoes are cultivated on large areas. In Poland, the most important potato pathogens include Potato virus Y (PVY), and particularly a new isolate of PVY from the subgroup of necrotic strains $\left(P V Y^{N}\right)$. Necrotic strains of potato virus are spreading now in Poland and have been responsible for $80-90 \%$ of PVY infection in potato fields in the last decade (Chrzanowska \& Doroszewska, 1997). Potato breeding involves the application of a number of natural resistance genes to PVY originating from different Solanum species. Obtaining new cultivars resistant to viral diseases through classic breeding involves a transfer of desired features from wild potato species, which is a long-lasting process. Genetic transformation might be a faster and more effective way of potato breeding, improving the efficiency of pathogen control (Jondedijk et al., 1992).

In the last decade, the method of genetic transformation has repeatedly been used in order to improve potato characteristics, including beneficial changes in the metabolism of protein, starch and sucrose (Prescha et al., 2002; Zuk et al., 2003; 2005), an increase of plant resistance to pathogenic fungi (Gazendam et al., 2004), bacterial pathogens (Pandey et al., 2005), and most of all resistance to Potato virus Y (Chachulska et al., 1997; Flis \& Zimnoch-Guzowska, 2000; Missiou et al., 2004). Information concerning the in vivo experiments with the genetic engineering plant products as dietary components is insufficient. In an experiment of Kosieradzka and coworkers (2004), genetic modification aimed at increasing the content of 14-3-3 protein in

^Presented at the International Review Conference on Biotechnology, Vienna, Austria, November 2004.

Abbreviations: ALT, alanine aminotransferase; AP, alkaline phosphatase; AST, aspartate aminotransferase; $\mathrm{CK}$, creatine kinase; GMO, genetically modified organism; LDH, lactate dehydratase; PVY, Potato virus Y; PVYN, necrotic strain of Potato virus Y; SCFA, short chain fatty acid; wt, wild type. 
potato plants has led, on the one hand, to changes in the nutritional value of tubers, and on the other hand, the administration of $20 \%$ dried tubers to diets for rats did not negatively affect the assayed growth parameters, digestibility of nutrients, blood morphology or most blood biochemical parameters. Transgenic potatoes with soybean glycinin included in diet neither influenced the diet intake and body mass gain, nor changed blood parameters as well as masses of internal organs, compared to animals fed diets containing conventional tubers (Hashimoto et al., 1999a; 1999b). In another experiment of Sanhoty and coworkers (2004), there were no statistical differences in the diet intake and body mass gain between rats fed genetically modified potatoes spunta with CryV gene and unmodified tubers. In an experiment of Böhme and coworkers (2005), genetic transformation of inulin synthesis in potatoes resulted in depression of starch content and fibre digestibility for pigs. After a feeding period of 42 days no plant DNA or DNA specific for the genome alteration in the transgenic potato were detected in gastrointestinal digesta or in the internal organs of pigs (Broll et al., 2005).

Most consumers are anxious of a potential GMO-related risk to their own or animal health. For this reason, the biological assessment of food and feeds from genetically modified plants is considered as advisable (Beever \& Kemp, 2000; Zduńczyk, 2001; Aumaitre et al., 2002, Flachowsky \& Böhme, 2005). The present report summarizes the results from experimental feeding of rats with a diet containing a high percentage of potato tubers genetically transformed to improve resistance to a necrotic strain of Potato virus Y. Special attention was paid to the nutritional properties of the diet, biochemical parameters of blood including indices of non-specific defence, as well as large-intestine metabolism parameters.

\section{MATERIAL AND METHODS}

The transgenic lines of potato were prepared at the Institute of Biochemistry and Biophysics of the PAS (Warszawa, Poland) (Chachulska et al., 1997). Plants of cultivar Irga were transformed with viral genome sequences in order to improve their resistance to a necrotic strain of Potato virus $Y\left(\mathrm{PVY}^{\mathrm{N}}\right)$. Four clones were chosen for the nutritional study:

- $\quad \mathbf{R} 1 F$ and $\mathbf{R 2 P}$ - transgenic lines with a truncated gene coding $\mathrm{PVY}^{\mathrm{N}}$ polymerase in the sense and antisense orientation, respectively;

- NTR1.16 and NTR2.27 - transgenic lines with non-translated regions of PVYN genome in the sense and antisense orientation, respectively.

Potato tubers obtained from the geneticallymodified potato lines were compared with two types of non-transgenic tubers: obtained from conventionally-bred cultivar Irga and from plants of somaclone Irga, regenerated and maintained in vitro under the same conditions as the transgenic lines (Irga wt). The transgenic lines and their conventional counterparts were multiplied at the Plant Breeding and Acclimatisation Institute (Research Centre Mlochow, Poland). All tubers used in the presented investigations were autoclaved $\left(121^{\circ} \mathrm{C}, 1013 \mathrm{hPa}, 15 \mathrm{~min}\right)$, dried $\left(40^{\circ} \mathrm{C}\right)$ and ground. Our investigations, involving 3-week feeding experiment on rats, included the following determinations: the chemical composition of tubers and nutritional properties of diets with high (40\%) content of tubers (Zduńczyk et al., 2005a), caecal metabolism, serum enzymes and indices of non-specific defence of rats (Zduńczyk et al., 2005b), and shortchain fatty acids (SCFA) production in the caecum of rats (Juśkiewicz et al., 2004).

\section{RESULTS}

Results in Table 1 show that the crude protein, starch and fibre content in dry matter of potato was comparable in tubers obtained from the conventional cultivar Irga, somaclone Irga and the transgenic lines. Also the content of essential amino acids in crude protein of transgenic potato was similar or higher than in tubers of the conventional cultivar Irga. A higher content of essential amino acids (i.e. leucine and lysine) was noticed for the transgenic line R2P.

Results in Table 2 indicate that supplementation diets with autoclaved potato tubers of conventional and transgenic lines did not influence the growth of animals. Feed intake as well as feed utilization were similar in all experimental groups. The activity of the enzymes analysed in the blood serum of rats was diversified not only between groups but also within each experimental group. Comparable activities of aspartate aminotransferase (AST), creatine kinase $(\mathrm{CK})$ and alkaline phosphatase $(\mathrm{AP})$ in all groups were measured. The activity of alanine aminotransferase (ALT) and lactate dehydratase (LDH) in the group fed with transgenic potato was within the range determined for the Irga group and the somaclone Irga group (Irga wt). Similar tendencies in the indices of non-specific resistance of rats were observed. In the groups fed diets containing tubers of the transgenic lines, the indices analysed were within the limits reported for the groups fed tubers of the conventionally bred cultivar or Irga somaclone. However, a lower percentage of phagocytic cells was found in the groups fed a diet with tubers of the transgenic lines R1F, NTR1.16 and NTR2.27.

Results in Table 3 show that in the group fed a diet with tubers of cultivar Irga and tubers of the transgenic lines a similar mass of the caecum wall 
Table 1. Indices of chemical composition of autoclaved and dried potato tubers (Zduńczyk et al., 2005a)

\begin{tabular}{|c|c|c|c|c|c|c|}
\hline & \multirow{2}{*}{ Irga } & \multirow{2}{*}{ Irga wt } & \multicolumn{4}{|c|}{ Transgenic line } \\
\hline & & & R1F & $\mathrm{R} 2 \mathrm{P}$ & NTR1.16 & NTR2.27 \\
\hline Dry matter, \% & 90.05 & 89.83 & 89.94 & 89.83 & 89.83 & 89.97 \\
\hline Crude protein, $\%$ & 10.00 & 9.81 & 9.94 & 9.95 & 10.25 & 10.10 \\
\hline Dietary fibre, \% & 8.87 & 9.26 & 8.77 & 8.88 & 9.78 & 9.32 \\
\hline Starch, \% & 76.65 & 75.96 & 76.18 & 76.58 & 74.68 & 76.24 \\
\hline Phe + Tyr & 6.68 & 6.68 & 6.84 & 7.44 & 6.86 & 6.71 \\
\hline Iso & 3.60 & 3.83 & 3.74 & 3.99 & 3.79 & 3.70 \\
\hline Leu & 5.77 & 5.97 & 5.94 & 6.30 & 6.05 & 5.82 \\
\hline Lys & 4.42 & 4.49 & 4.45 & 4.67 & 4.48 & 4.46 \\
\hline Met + Cys & 3.33 & 3.37 & 3.42 & 3.36 & 3.43 & 3.46 \\
\hline Thr & 3.50 & 3.59 & 3.60 & 3.66 & 3.56 & 3.44 \\
\hline Val & 5.53 & 5.59 & 5.49 & 5.85 & 5.70 & 5.49 \\
\hline$\Sigma \mathrm{EAA}^{1}$ & 38.14 & 38.90 & 38.87 & 40.88 & 39.52 & 38.45 \\
\hline$\Sigma \mathrm{EAA}, \% \Sigma \mathrm{AA}^{2}$ & 44.1 & 43.8 & 44.6 & 45.1 & 44.2 & 44.5 \\
\hline
\end{tabular}

${ }^{1} \Sigma$ EAA, total essential amino acids; ${ }^{2} \Sigma \mathrm{AA}$, total amino acids.

Table 2. Results of feeding experiment ${ }^{1}$, activity of serum enzymes ${ }^{2}$ and indices of non-specific resistance of rats ${ }^{3}$ (Zduńczyk et al., 2005b)

\begin{tabular}{lcclcccc}
\hline & \multirow{2}{*}{ Irga } & \multirow{2}{*}{ Irga wt } & \multicolumn{3}{l}{ Transgenic clone } & & \\
\cline { 5 - 8 } & & & R1F & R2P & NTR1.16 & NTR2.27 & S.E.M. \\
\hline IBW, g & 122.7 & 122.7 & 122.6 & 122.6 & 122.6 & 122.7 & 0.01 \\
FBW, g & 213.4 & 212.6 & 213.7 & 212.1 & 209.7 & 212.1 & 1.21 \\
DI, g/day & 17.70 & 17.45 & 17.21 & 17.57 & 17.32 & 17.45 & 0.06 \\
BWG g/day & 4.32 & 4.28 & 4.34 & 4.26 & 4.15 & 4.26 & 0.05 \\
FCR, g/g & 4.12 & 4.09 & 4.00 & 4.15 & 4.21 & 4.13 & 0.05 \\
ALT, IU/I & $21.6^{\mathrm{b}}$ & $28.3^{\mathrm{a}}$ & $26.6^{\mathrm{ab}}$ & $28.8^{\mathrm{a}}$ & $26.8^{\mathrm{ab}}$ & $22.4^{\mathrm{b}}$ & 0.74 \\
AST, IU/I & 165 & 182 & 156 & 161 & 166 & 180 & 4.32 \\
CK, IU/I & 1289 & 1099 & 1580 & 1461 & 1342 & 1194 & 69.6 \\
AP, IU/I & 589 & 501 & 591 & 514 & 502 & 557 & 22.8 \\
LDH, IU/I & $1296^{\mathrm{b}}$ & $1846^{\mathrm{a}}$ & $1497^{\mathrm{ab}}$ & $1393^{\mathrm{ab}}$ & $1559^{\mathrm{ab}}$ & $1390^{\mathrm{ab}}$ & 67.2 \\
Protein, g/dl & $4.04^{\mathrm{b}}$ & $5.56^{\mathrm{a}}$ & $5.25^{\mathrm{a}}$ & $5.05^{\mathrm{a}}$ & $5.49^{\mathrm{a}}$ & $5.06^{\mathrm{a}}$ & 0.10 \\
CRP, mg/dl & $19.41^{\mathrm{c}}$ & $26.37^{\mathrm{a}}$ & $23.35^{\mathrm{ab}}$ & $20.70^{\mathrm{b}}$ & $23.01^{\mathrm{ab}}$ & $22.50^{\mathrm{ab}}$ & 0.61 \\
LYSE, Ug/dl & $3.56^{\mathrm{c}}$ & $4.53^{\mathrm{a}}$ & $4.67^{\mathrm{a}}$ & $4.70^{\mathrm{a}}$ & $3.96^{\mathrm{abc}}$ & $4.31^{\mathrm{ab}}$ & 0.12 \\
PHAG, \% & $83.3^{\mathrm{a}}$ & $83.3^{\mathrm{a}}$ & $66.7^{\mathrm{a}}$ & $81.7^{\mathrm{ab}}$ & $73.3^{\mathrm{bc}}$ & $73.3^{\mathrm{bc}}$ & 1.46 \\
PKA & 0.218 & 0.172 & 0.219 & 0.214 & 0.213 & 0.215 & 0.01 \\
BAS & $14.7^{\mathrm{a}}$ & $13.4^{\mathrm{a}}$ & $11.0^{\mathrm{b}}$ & $13.0^{\mathrm{a}}$ & $13.4^{\mathrm{a}}$ & $12.8^{\mathrm{ab}}$ & 0.20 \\
\hline
\end{tabular}

${ }^{1} \mathrm{IBW}$, initial body mass; FBW, final body mass; DI, diet intake; BWG, body mass gain; FCR, feed efficiency ratio: g diet intake/g BWG; ${ }^{2} \mathrm{ALT}$, alanine aminotransferase; AST, aspartate aminotransferase; AP, alkaline phosphatase; LDH, lactate dehydratase; CK, creatine kinase; ${ }^{3}$ Protein, CRP, ceruloplasmine; LYSE, lysozyme; PHAG, percentage of phagocytic cells; PKA, potential killing; BAS, number of bacterial absorbed per cell. a, b, c, Values in one row having different superscripts are significantly different at $\mathrm{P} \leq 0.05$; S.E.M., standard errors of the means (standard deviation for all rats divided by square root of rat number, $n=48$ ).

was determined. The mass of caecal digesta of rats fed diets with tubers of transgenic line NTR2.27 was significantly higher than in the groups Irga wt and R1F.

The lowest hydration of caecal digesta was found in groups R2P and NTR1.16, while the highest one in the group R1F. The relatively content of dry matter per caecum was similar in these groups. The highest amount of dry matter in the caecum was determined in the group NTR2.27. The caecal $\mathrm{pH}$ in the group NTR1.16 was higher, especially compared to non-transgenic Irga wt No significant differences were observed for the activities of $\alpha$ - and $\beta$-glucosidase, $\alpha$ - and $\beta$-galactosidase and $\beta$-glucuronidase in the caecal digesta of rats fed diets containing tubers of the Irga cultivars and the transgenic lines. The highest production of total SCFA as well as of the major acids (acetic, propionic and butyric) was found in the caecum of rats fed diet with tubers of transgenic line NTR2.27. Lower values of SCFA content were observed especially in the groups $\mathrm{R} 1 \mathrm{~F}$ and $\mathrm{R} 2 \mathrm{P}$. 
Table 3. Caecal parameters, bacterial enzyme activity and production of short chain fatty acids (SCFA) in caecum of rats (Juśkiewicz et al., 2004, Zduńczyk et al., 2005b)

\begin{tabular}{|c|c|c|c|c|c|c|c|}
\hline & \multirow{2}{*}{ Irga } & \multirow{2}{*}{ Irga wt } & \multicolumn{4}{|c|}{ Transgenic line } & \multirow{2}{*}{ SEM } \\
\hline & & & R1F & R2P & NTR1.16 & NTR2.27 & \\
\hline \multicolumn{8}{|l|}{ Caecal parameters $^{1}$} \\
\hline Empty caecum, g & 0.28 & 0.29 & 0.27 & 0.30 & 0.28 & 0.28 & 0.01 \\
\hline Caecum content, g & $0.98^{\mathrm{ab}}$ & $0.90^{\mathrm{b}}$ & $0.87^{\mathrm{b}}$ & $0.95^{\mathrm{ab}}$ & $0.99^{\mathrm{ab}}$ & $1.09^{\mathrm{a}}$ & 0.02 \\
\hline Dry mater, \% & $18.6^{\mathrm{ab}}$ & $18.7^{\mathrm{ab}}$ & $20.5^{\mathrm{a}}$ & $17.6^{\mathrm{b}}$ & $18.0^{\mathrm{b}}$ & $19.3^{\mathrm{ab}}$ & 0.29 \\
\hline Dry mater, g & $0.178^{\mathrm{b}}$ & $0.171^{\mathrm{b}}$ & $0.179^{\mathrm{b}}$ & $0.170^{\mathrm{b}}$ & $0.178^{\mathrm{b}}$ & $0.204^{\mathrm{a}}$ & 0.01 \\
\hline $\mathrm{pH}$ & $6.99^{\mathrm{ab}}$ & $6.89^{\mathrm{b}}$ & $7.03^{\mathrm{ab}}$ & $7.08^{\mathrm{ab}}$ & $7.21^{\mathrm{a}}$ & $6.99^{\mathrm{ab}}$ & 0.04 \\
\hline \multicolumn{8}{|l|}{ Enzyme activity, U/g } \\
\hline$\alpha$-Glucosidase & 1.48 & 1.84 & 1.66 & 1.95 & 1.92 & 1.80 & 0.08 \\
\hline$\beta$-Glucosidase & 0.34 & 0.45 & 0.46 & 0.37 & 0.39 & 0.45 & 0.02 \\
\hline$\alpha$-Galactosidase & $0.80^{\mathrm{b}}$ & $1.47^{\mathrm{a}}$ & $0.89^{\mathrm{b}}$ & $1.12^{\mathrm{ab}}$ & $0.91^{\mathrm{b}}$ & $0.84^{\mathrm{b}}$ & 0.07 \\
\hline$\beta$-Galactosidase & $3.85^{\mathrm{b}}$ & $5.29^{\mathrm{a}}$ & $3.88^{\mathrm{b}}$ & $4.85^{\mathrm{ab}}$ & $4.29^{\mathrm{ab}}$ & $4.35^{\mathrm{ab}}$ & 0.21 \\
\hline$\beta$-Glucuronidase & 0.71 & 0.68 & 0.60 & 0.42 & 0.59 & 0.58 & 0.04 \\
\hline \multicolumn{8}{|c|}{ SCFA production $^{1}, \mu$ mol } \\
\hline Total & $64.75^{\mathrm{b}}$ & $64.45^{\mathrm{b}}$ & $52.78^{\mathrm{cd}}$ & $50.40^{\mathrm{cd}}$ & $58.91^{b c}$ & $73.92^{\mathrm{a}}$ & 2.23 \\
\hline Acetate & $46.68^{\mathrm{ab}}$ & $47.23^{\mathrm{ab}}$ & $38.03^{b c}$ & $36.39^{c}$ & $42.22^{\mathrm{b}}$ & $53.46^{\mathrm{a}}$ & 1.62 \\
\hline Propionate & 8.65 & 7.78 & 7.30 & 7.08 & 8.40 & 9.49 & 0.34 \\
\hline Isobutyrate & $0.79^{\mathrm{ab}}$ & $0.85^{\mathrm{ab}}$ & $0.82^{\mathrm{ab}}$ & $0.62^{\mathrm{b}}$ & $0.77^{\mathrm{ab}}$ & $0.97^{\mathrm{a}}$ & 0.03 \\
\hline Butyrate & $6.34^{\mathrm{ab}}$ & $6.16^{\mathrm{ab}}$ & $4.75^{\mathrm{c}}$ & $4.51^{\mathrm{c}}$ & $5.27^{\mathrm{bc}}$ & $7.22^{\mathrm{a}}$ & 0.28 \\
\hline Isovalerate & 0.91 & 0.88 & 0.87 & 0.74 & 0.88 & 1.02 & 0.04 \\
\hline Valerate & $1.37^{\mathrm{b}}$ & $1.56^{\mathrm{ab}}$ & $1.02^{\mathrm{c}}$ & $1.05^{\mathrm{c}}$ & $1.38^{\mathrm{b}}$ & $1.75^{\mathrm{a}}$ & 0.06 \\
\hline
\end{tabular}

${ }^{1}$ Calculated to $100 \mathrm{~g}$ body mass of rats. a, b, c, d, Values in one row having different superscripts are significantly different at $P \leq 0.05$.

\section{DISCUSSION}

The results obtained in the present study indicate that genetic modification of potato in order to improve their resistance to a necrotic strain of Potato virus $Y\left(\mathrm{PVY}^{\mathrm{N}}\right)$ had no effect on the chemical composition (e.g., crude protein, starch, dietary fibre content and amino-acid composition of protein) and nutritional properties of tubers (diet intake and animal growth). In our original paper (Zduńczyk et al., 2005a; 2005b), we described in details that greater differences between chemical composition (especially in crude protein and starch content) and biological response of rats were observed between tubers from conventional potato cultivars Irga, Ania and Maryna. The obtained results are confirmed by other researchers who worked with plants with genetically improved tolerance to herbicides and plants resistant to diseases. There were no differences in chemical composition between genetically modified potatoes and their conventional ancestor lines (Hashimoto et al., 1999a; 1999b; Rogan et al., 2000). Results of in vivo experiments of the above-mentioned authors indicated that tubers of transgenic clones with improved virus- or insect-resistance were nutritionally equivalent to their conventional counterparts. In our study, the chemical composition of tubers and physiological response of rats to experimental diets indicate that transgenic potatoes with genetically-improved resistance to PVYN may be substantially and nutritionally equivalent to the non-transgenic culti- var. However, the results obtained are insufficient to explain some deviations, e.g., the higher content of essential amino acids in tubers of line R2P, the higher enzymatic activity in the caecal content of rats fed a diet with tubers of somaclone Irga, and especially the increased bulk of caecal digesta and higher production SCFA in the caecum of rats fed diet with tubers of the NTR2.27 line. For that reason, a longterm feeding study is necessary to confirm the nutritional properties of tubers of the transgenic lines. A long-term feeding study should allow showing, that genetic transformation of potato (with a truncated gene coding $P V Y^{N}$ polymerase or non-translated regions of the $P V Y^{N}$ genome, both in sense and antisense orientation), is acceptable with regard to the nutritional and physiological properties of tubers.

\section{CONCLUSION}

Concerning the analysed parameters of the chemical composition of tubers and the physiological response of rats to experimental diets, tubers of transgenic line R1F (truncated gene coding for PVYN polymerase in sense orientation), R2P (truncated gene coding for $P V Y^{\mathrm{N}}$ polymerase in antisense orientation), and NTR1.16 (non-translated regions of $\mathrm{PVY}^{\mathrm{N}}$ genome in sense orientation) were similar to tubers of the conventional cultivar Irga. Tubers of transgenic line NTR2.27 (non-translated regions of $\mathrm{PVY}^{\mathrm{N}}$ genome in antisense orientation) increased the 
bulk of caecal digesta and the production of SCFA as compared to tubers of the conventional cultivar and the other transgenic clones. Taking into account some deviations, e.g., the higher content of essential amino acids in tubers of line R2.P, higher enzymatic activity in caecal digesta of rats fed a diet with tubers of somaclone Irga, and especially the increased amount of caecal digesta and higher production SCFA in the caecum of rats fed a diet with tubers of line NTR2.27, it seems reasonable to undertake a long-term feeding study to confirm the nutritional properties of tubers of transgenic lines.

\section{REFERENCES}

Aumaitre A, Aurlich K, Chesson A, Flachowsky G, Piva G (2000) New feeds from genetically modified plants: Substantial equivalence, nutritional equivalence, digestibility, and safety for animals and the food chain. Livest Prod Sci 74: 223-238.

Beever DE, Kemp CF (2000) Safety issues associated with DNA in animal feed derived from genetically modified crops. A review of scientific and regulatory procedures. Nutr Abstr Rev Ser B 70: 175-182.

Böhme H, Hommel B, Flachowsky G (2005) Nutritional assesment of silage from transgenic inulin synthesis potatoes for pigs. J Anim Feed Sci 14 (Suppl. 1): 333-336.

Broll H, Zagon J, Butschke A, Leffke A, Spiegelberg A, Böhme H, Flachowsky G (2005) The fate of DNA of transgenic inulin synthesizing potato in pigs. J Anim Feed Sci 14 (Suppl 1): 337-340.

Chachulska AM, Chrzanowska M, Flis B, Krzymowska M, Lipska-Dwużnik A, Robaglia C, Zagórski W (1997) Potato and tobacco cultivars transformation towards potato virus resistance. Biotechnologia 4: 48-54.

Chrzanowska M, Doroszewska T (1997) Comparison between PVY isolates obtained from potato and tobacco plants grown in Poland. Phytopathol Polon 8: 15-20.

Flachowsky G, Böhme H (2005) Proposal for nutritional assessment of feeds for genetically modifies plants. J Anim Feed Sci 14 (Suppl. 1): 49-70.

Flis B, Zimnoch-Guzowska E (2000) Field performance of transgenic clones obtained from potato cv. Irga. I Appl Genet 41: 81-90.

Gazendam I, Oelofse D, Berer DK (2004) High-level expression of apple PGIP1 is not sufficient to protect transgenic potato against Verticillum dahliae. Physiol Mol Plant 65: 145-155.

Hashimoto W, Momma K, Katsube T, Ohkawa Y, Ishige T, Kito M, Utsumi S, Murata K (1999a) Safety assessment of genetically engineered potatoes with designed soybean glycinin: compositional analyses of the potato tubers and digestibility of the newly expressed protein in transgenic potatoes. J Sci Food Agric 79: 1607-1612.

Hashimoto W, Momma K, Yoon HJ, Ozawa S, Ohkawa Y, Ishige T, Kito M, Utsumi S, Murata K (1999b) Safety assessment of transgenic potatoes with soybean glycinin by feeding studies in rats. Biosci Biotechn Biochem 63: 1942-1946.

Jondedijk E, De Schutter AAJM, Sollte T, van den Elzen PJM, Cornelissen BJC (1992) Increased resistance to potato virus $X$ and preservation of cultivar properties in transgenic potato under field condition. Bio/Technology 10: $422-429$.

Juśkiewicz J, Zduńczyk Z, Frejnagel S, Fornal J (2004) Caecal fermentation in rats fed diets containing tubers of transgenic potato. J Animal Feed Sci 13 (Suppl 2): 93-96.

Kosieradzka I, Sawosz E, Pastuszewska B, Zuk M, Szopa J, Bielecki W (2004) Effect of feeding potato tubers modified by 14-3-3 protein overexpession on metabolism and health status of rats. J Anim Feed Sci 13: 329-339.

Missiou A, Kalantidis K, Boutla A, Tzortzakaki S, Tabler M, Tsagris M (2004) Generation of transgenic potato plants highly resistant to Potato virus Y (PVY) through RNA silencing. Mol Breeding 14: 185-197.

Prescha A, Biernat J, Szopa J (2002) Quantitative and qualitive analysis of lipids in genetically modified potato tubers with varying rates of 14-3-3 protein synthesis. Nahrung 46: 179-183.

Rogan GJ, Bookout JT, Duncan DR, Fuchs RL, Lavrik PB, Love SL, Mueth M, Olson T, Owens ED, Raymond PJ, Zalewski J (2000) Compositional analysis of tubers from insect and virus resistant potato plants. J Agric Food Chem 48: 5936-5945.

Sanhoty L, EL-Rahman AA, Bolg KW (2004) Quaity and safety evaluation of genetically modified potatoes spunta with $\mathrm{CryV}$ gene: compositional analysis, determination of some toxins, antinutriens compounds and feeding study in rats. Nathrung 48: 8-13.

Zduńczyk Z (2001) In vivo experiments on the safety evaluation of GM components of feeds and foods. J Anim Feed Sci 10 (Suppl. 1): 195-210.

Zduńczyk Z, Frejnagel S, Fornal J, Flis M, Palacios MC, Flis B, Zagórski-Ostoja W (2005a) Biological response of rat fed diets with high tuber content of conventionally bred and transgenic potato resistant to necrotic strain of Potato virus Y $\left(\mathrm{PVY}^{\mathrm{N}}\right)$. Part. I. Chemical composition of tubers and nutritional value of diets. Food Control 16: 761-766.

Zduńczyk Z, Juśkiewicz J, Fornal J, Mazur-Gonkowska B, Koncicki A, Flis B, Zimnoch-Guzowska E, ZagórskiOstoja W (2005b) Biological response of rat fed diets with high tuber content of conventionally bred and transgenic potato resistant to necrotic strain of Potato virus $Y\left(\mathrm{PVY}^{\mathrm{N}}\right)$. Part. II. Caecal metabolism, serum enzymes and indices of non-specific defence of rats. Food Control 16: 767-772.

Zuk M, Prescha A, Kępczyński J, Szopa J (2003) ADP ribosylation factor regulates matabolism and antioxidant capacity of transgenic potato tubers. I Agric Food Chem 51: 288-294.

Zuk M, Weber R, Szopa J (2005) 14-3-3 protein down-regulates key enzyme activities of nitrate and carbohydrate metabolism in potato plants. I Agric Food Chem 53: 3454-3460. 